\begin{tabular}{|l|l|l||}
\hline \multicolumn{2}{|c|}{ PublisherInfo } \\
\hline \hline PublisherName & $:$ & BioMed Central \\
\hline \hline PublisherLocation & $:$ & London \\
\hline \hline PublisherImprintName & $:$ & BioMed Central \\
\hline \hline
\end{tabular}

\title{
Data access concerns
}

\begin{tabular}{|l|l|l||}
\hline \multicolumn{2}{|c|}{ ArticleInfo } \\
\hline \hline ArticleID & $:$ & 4586 \\
\hline \hline ArticleDOI & $:$ & $10.1186 /$ gb-spotlight-20020919-02 \\
\hline \hline ArticleCitationID & $:$ & spotlight-20020919-02 \\
\hline \hline ArticleSequenceNumber & $:$ & 252 \\
\hline \hline ArticleCategory & $:$ & Research news \\
\hline ArticleFirstPage & $:$ & 1 \\
\hline \hline ArticleLastPage & $:$ & 3 \\
\hline \hline & & RegistrationDate : 2002-9-19 \\
\hline ArticleHistory & $:$ & OnlineDate \\
\hline \hline ArticleCopyright & $:$ & BioMed Central Ltd2002-9-19 \\
\hline \hline ArticleGrants & $:$ & \\
\hline \hline ArticleContext & $:$ & 130593311 \\
\hline \hline
\end{tabular}


A recent U.S. National Academy of Sciences (NAS) symposium titled "The Role of Scientific and Technical Data and Information in the Public Domain" tackled the latest twists in an ongoing debate over the ownership and distribution of scientific and technical data. At the meeting, held 5 and 6 September in Washington, D.C., scientists, lawyers and policymakers addressed the implications of the increasing economic, legal and technological pressures to make large databases proprietary.

Scientists and engineers continue to churn out massive amounts of data related to everything from genomes to weather to computer software code. But some worry that pressures to privatize or legally restrict database access could hamper the scientific and technological enterprises by impeding the traditional free exchange of research results.

"There's a general presupposition that public science requires openness," explained symposium organizer Paul Uhlir, director of International Scientific \& Technical Information Programs at the NAS. "Ultimately you need access to the underlying facts and the sources for research in order to verify the research findings that are published and to do further work - science builds on science. If you don't have that kind of transparency and access to that information, the system breaks down," Uhlir told The Scientist.

Meeting topics ranged from ways to encourage informal information exchange among laboratories, to measures for strengthening mechanisms that ensure public access to data - including public archives, libraries, data centers, and open Web sites.

Participants, for example, discussed successful public-private partnerships. Michael Morgan of the Wellcome Trust cited the SNP Consortium, formed three years ago when partners from industry and academia pooled their resources. The group has identified several hundred thousand single nucleotide polymorphisms (SNPs), common DNA sequence variations that could point the way toward disease treatments. And they made their SNP map publicly available, giving no advanced access to members.

Other partnerships have failed to materialize, however. In 2000, attorney and University of California, Berkeley lecturer Stephen Maurer helped academic biologists negotiate a $\$ 3.2$ million memorandum of understanding with Incyte Genomics to start a large database archive that would have unified several disparate human mutations databases. In exchange, Incyte would have had exclusive rights to host the database on its Web site, though the database would be freely available to all. However, academic partners balked, according to Maurer, fearing that Incyte would have too much control.

Possible barriers to data exchange were also discussed at the symposium. These may include national security concerns, as well as further restrictions from increasingly financially-strapped government and university producers of scientific data.

New legislation that boosts database protections could hinder data exchange as well. Some scientists have expressed concern over a European Union directive, already enacted, that could prevent the free use of "factual data." The directive is meant to protect the fruits of database creators' labors. Though cases of research roadblocks in the EU have yet to be cited, Uhlir worries that scientists, engineers, or 
others may simply choose to redirect their research efforts rather than fighting restrictions. "Such effects are hard to measure," Uhlir said.

\section{References}

1. "Symposium on the Role of Scientific and Technical Data and Information in the Public Domain." (Agenda and speaker abstracts), [http://www7.nationalacademies.org/biso/

Public\%20Domain\%20Symposium\%20Announcement.html]

2. NAS Office of International Scientific \& Technical Information Programs, [http://www7.nationalacademies.org/biso/ISTIP.html]

3. Wellcome Trust, [http://www.wellcome.ac.uk/]

4. The SNP Consortium, [http://brie2.cshl.org/index.html]

5. University of California, Berkeley, [http://www.berkeley.edu/]

6. Russo, E: EU database directive draws fire. The Scientist, 8 July, 2002., [http:/www.thescientist.com/yr2002/jul/russo_p18_020708.html] 